\title{
ANALYSIS OF ECONOMIC AND ENVIRONMENTAL EFFECTS OF LAND CONSOLIDATION ON THE EXAMPLE OF HUCISKO VILLAGE
}

\author{
Przemysław Leń', Żanna Król' \\ 1 Department of Environmental Engineering and Geodesy, University of Life Sciences in Lublin, Leszczyńskiego \\ Str. 7, 20-069 Lublin, Poland, e-mail: przemyslaw.len@up.lublin.pl, zannakrol.up@o2.pl
}

Received: 2016.08.01 Accepted: 2016.09.26 Published: 2016.11.01

\begin{abstract}
The paper presents the analysis of the economic and environmental effect of land consolidation on the example of the village of Hucisko situated in the administrative district of Leżajsk, Podkarpackie Province. Rural areas in Poland need changes related with an improvement of their competitive position in the European market. The object of the study is situated in the Podkarpackie Province which is characterised by fairly high land fragmentation and the occurrence of irregular-shaped and relatively small plots. Farms in South and South-Eastern Poland require modification with regard to their size or to the shape of their area. Within the area under analysis, land consolidation was performed in the years 2011-2013. The main purpose of the consolidation was to eliminate the troublesome checkerboard of fields. The performed land consolidation contributed to a significant improvement of living and work conditions of the local inhabitants. It can be also stated that the quality of the environment and the cultural values of the village have been enhanced.
\end{abstract}

Keywords: land consolidation, checkerboard of fields, environmental effects, economic effects

\section{INTRODUCTION}

A characteristic feature of Polish farms is their strong fragmentation which is a result of the agricultural policy in post-war Poland. Considerable fragmentation of farmland can be observed in the south-eastern part of Poland. In the region of Podkarpacie the farms are characterised by a large number of plots with irregular shapes and small areas, as evidenced in numerous studies [Leń P., Noga K., 2010] [Leń P., 2010], [Leń P. et al. 2015a,b], [Leń P., Mika M. 2016a]. In turn, the farmlands of individual farms in central Poland [Wójcik G., Leń P. 2015], apart from notable fragmentations, are characterised by strong elongation of plots. A similar phenomenon is observed in eastern Poland [Król Ż. 2014]. The situation is aggravated by large scattering of farmland of individual farms. In the literature one can fairly often encounter the statement that the checkerboard of individual farms has a negative effect on the organisation and level of agricultural production [Noga 2001, Noga Schilbach 1993, Dudzińska 2012, Gniadek 2013]. A study conducted in the area of the Podkarpackie Province, in the Brzozowski District [Leń P. 2009, 2012], showed that every fourth plot belonging to private owners is situated in a farmland checkerboard. A similar situation is observed in the locality of Olszanica, Leski District [Leń P. et al. 2015c]. In the village Będziemyśl, situated in the RopczyckoSędziszowski District, every fifth plot is the property of non-local non-resident owners [Leń P. et al. 2015d]. Research concerning the scatter of farmland in central Poland also revealed considerable deficiencies. In the villages of Commune Sławno, 4146.45 ha of farmland is situated in the outer patchwork of grounds, which constitutes $40.9 \%$ of the total area of farmland of individual farms. That area is composed of 10299 registered land lots which account for $43.1 \%$ of the total number of plots in the private sector. Those 
plots are the property of 3716 owners [Leń P. et al. 2016]. In turn, in the village Brzustowiec, a study showed that 516 registered land lots are the property of non-local non-resident owners, which constitutes $26.9 \%$ of the total number of lots on individual farms. Their combined area is 145.4 ha, i.e. $23.8 \%$ of the total area of private farmland [Leń P., Mika M. 2016b,c]. Research conducted in Commune Cyców, Lublin Province, also revealed notable scattering of plots of individual farms [Król, Leń 2016]. Estimated data indicate that in Poland there is approximately 3 million hectares of farmland in plot patchwork layout.

In 2003 the European Union introduced changes concerning the Common Agricultural Policy. According to the Ministry of Agriculture and Rural Development, the priority in the development of rural areas should be the economic development which enhances the attractiveness of those areas and strengthens the agricultural sector while preserving the natural environment. The implementation of those objectives requires the following:

- living and working conditions of village inhabitants that will allow their economic, educational, cultural and social self-realization;

- improvement of spatial structure of farms and their modernisation;

- protection of the natural environment and cultural heritage through the implementation of organic agriculture and management of marginal soils [Sobolewska-Mikulska, 2005].

Land consolidation plays an important role in the consolidation of farmlands and in the improvement of spatial structure of Polish agriculture. One of the primary objectives of land consolidation is "the transformation of the spatial structure of fragmented plots, distributed in a checkerboard pattern, into shapely plots with convenient access" [Sobolewska-Mikulska, Pułecka, 2007]. The process of land consolidation eliminates enclaves, semi-enclaves, straightens the boundary lines of villages, and also designs a new communication system of rural areas. It also allows access to plots and reduces the distance between the habitation and the farming plots. Land consolidation operations currently conducted in the territory of Poland "permit an increase of economic effectiveness of farming and a reduction of production costs, labour outlays, commuting time and fuel consumption" [Sobolewska-Mikulska, Pułecka, 2007]. The aim of modern land consoli- dation is also the management and conservation of the natural environment of rural areas through agricultural diversification:

- limitation of soil erosion by means of special formation of farmland areas and of roads used for framing transport;

- maintenance and care of existing mid-field tree lines and groups and the design of new ones for the improvement of microclimate of areas with low level of afforestation;

- creation of ecological corridors (afforestation) conducive to the migration of animals;

- conservation of buffer zones around water reservoirs for their protection against synthetic plant protection agents and fertilisers [Trystuła, 2008].

The objective of the study was to analyse the economic and environmental effects of land consolidation on the example of the village Hucisko. The object of the analysis is situated in commune Leżajsk, Leżajsk District, Podkarpackie Province. Rural areas in Poland require changes related with improving their competitiveness on the European market. The object of the study is situated in the Podkarpackie Province which is characterised by fairly high land fragmentation and occurrence of irregular-shaped and relatively small plots. Farms in South and South-Eastern Poland require modification with regard to their size or to the shape of their area.

\section{MATERIAL AND METHODS}

The village Hucisko is situated in commune Leżajsk, Leżajsk District, Podkarpackie Province. In the study presented here an attempt was made at an analysis of the economic and environmental effects of land consolidation performed within the area under analysis. The presented assumptions were realized and subjected to evaluation in the aspect of improvement of the development of rural areas. The total area of the object of analysis is 579.34 ha, out of which the process of land consolidation was applied on 438.37 ha. That area is divided into 2383 registered land lots. The area covered by the consolidation consists mainly of farmland (350.30 ha). The remaining part is forests - including grounds of the National State Forests (140.97 ha) and lands covered with trees and bushes, roads, and fallows. 


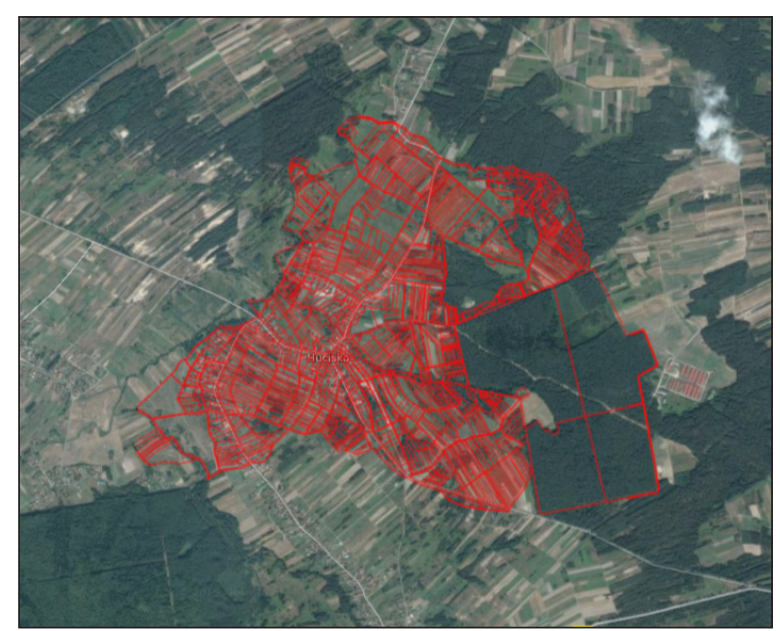

Fig. 1. The object prior to the consolidation, presented on the basis of an orthophotomap

The dominant form of land use in the area covered by the consolidation is farmland which occupies an area of 187.69 ha, which accounts for $61.1 \%$ of the area of the village under analysis. The farmland consists of arable lands -187.69 ha $(32.4 \%)$, orchards -0.29 ha $(0.1 \%)$, meadows -42.09 ha $(7.3 \%)$, pastures -96.64 ha $(16.7 \%)$, built-up arable lands -25.66 ha (4.4\%), land under ponds -0.06 ha, which constitutes a negligible percentage, and ditches with a combined area of 1.65 ha, which constitutes $0.3 \%$ of the area under study. Note should also be taken of land under forest use, occupying an area of $200.32 \mathrm{ha}$, which constitutes $34.6 \%$ of the entire area of Hucisko. That area includes 185.43 ha of forests (32\%) and 14.89 ha $(2.6 \%)$ of lands covered with trees and bushes. Built-up and urbanised lands -17.92 ha $(3.1 \%)$ - are mainly transport areas that occupy 13.98 ha $(2.4 \%)$. Lands under water are only running surface waters and constitute $0.66 \mathrm{ha}$, which is $0.1 \%$ of the area of the village. The remaining farmlands constitute a negligible percentage. Fallows occupy 6.37 ha, which constitutes $1.1 \%$ of the entire area of Hucisko.

The forests, with average nature-landscape values, occur mainly in the eastern part of the village, in the form of an integrated complex. They are characterised by a domination of fresh forest habitats that, as we move eastwards, change to mixed fresh forest habitats, fresh mixed coniferous forest habitats and fresh coniferous forest habitats. The dominant vegetation there is the Carpathian beech wood assemblage, i.e. beech with fir, pine and common oak. Within the area of Hucisko there are 185.43 ha of forests $(32,01 \%)$, out of which 140.97 ha belonging to the National
State Forests -Leżajsk Forest Inspectorate, which constitutes $24.3 \%$ of the entire area of the village.

Tree- and bush-covered lands constitute a small part of the area of the village - 14.89 ha $(2.57 \%)$ [Information Chart of the Project ..., 2011].

The forest areas and the tree- and bush-covered lands in the area of the village under study are illustrated in the photographs below.

The diversified geological structure of the area has an impact on the diversity of the resources of underground waters. The most important are the waters in the quaternary formations, that provide the basic water supply for the farms, municipal intakes, and village mains water supply systems. An elevated level of waters occurs on the meadows, in spite of the existence of melioration ditches. The melioration system in Hucisko is 5.7 $\mathrm{km}$ long. The existing drainage ditches require conservation and renovation. Their low draining throughput is caused the low slope of the terrain, which is illustrated in photo 3 .

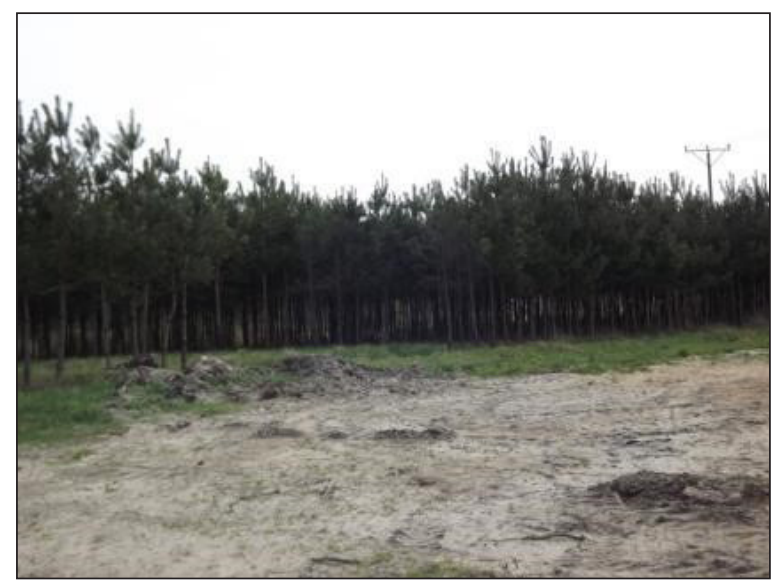

Photo 1. Example of coniferous forest in Photo 2

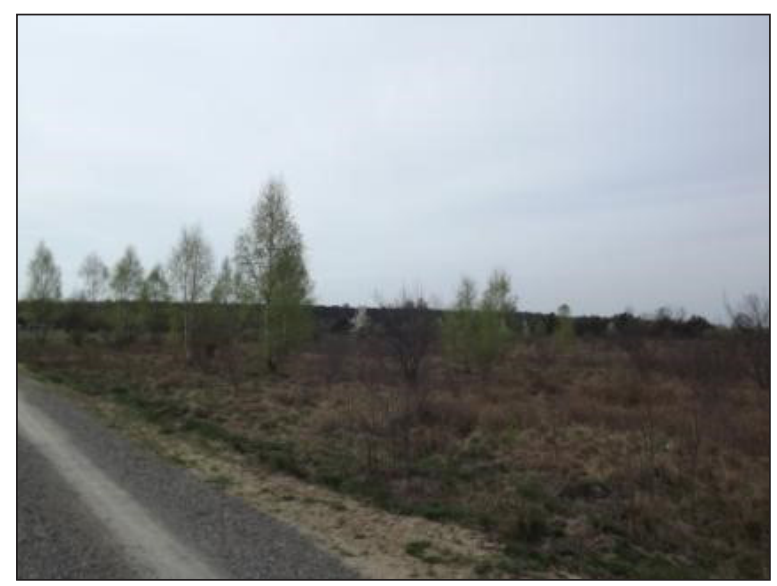

Photo 2. Example of mid-field bush- and tree- the area covered by the consolidation covered lands occurring in the area covered by the consolidation 


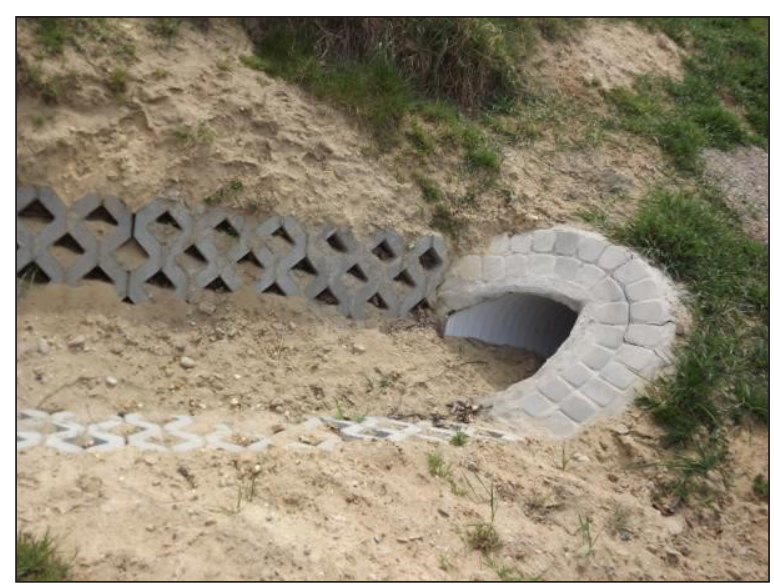

Photo 3. Example of newly-built drainage ditch in the area covered by the consolidation

In Hucisko there are frequent flooding events, caused also by the small slope of the ground and low throughput of the drainage ditches. The ditches discharge water into the river Tarlaka which is a part of the catchment system of the river San.

The soils in the area of the village Hucisko are podzolic proper and pseudopodzolic, as well as brown soils developed on sands. This is reflected in the complexes of agricultural suitability of soils of arable lands and grasslands. To a large extent the soils in the village are classified in classes IVa, IVb, V, VI, and on small fragments on the area they are of classes IIIa and IIIb.

In drainage-less depressions of the terrain there formed peat soils on which assemblages of marshy coniferous forest develop. Most of the peatbogs in the area of the village have been drained and planted with pine, birch, aspen and spruce. The examples below present peatlands overgrown with birch [Assumption to the land consolidation project..., 2011].

The average area of a registered land lot of the farmland of the individual farms in the village under study is 0.18 ha. Compared to the optimum plot area, the plots in the village differ considerably from the norm adopted in the Province, in the country and in the European Union. This has a highly negative effect on the achievement of any profits from agriculture. Plots with area up to 0.10 are cannot be included in applications for direct payments from the European Union. This is an enormous economic loss to the owners of such plots. In accordance with the Act of 1997, farmland plots with area up to 0.30 ha cannot by further divided [Act, 1997]. On the basis of the

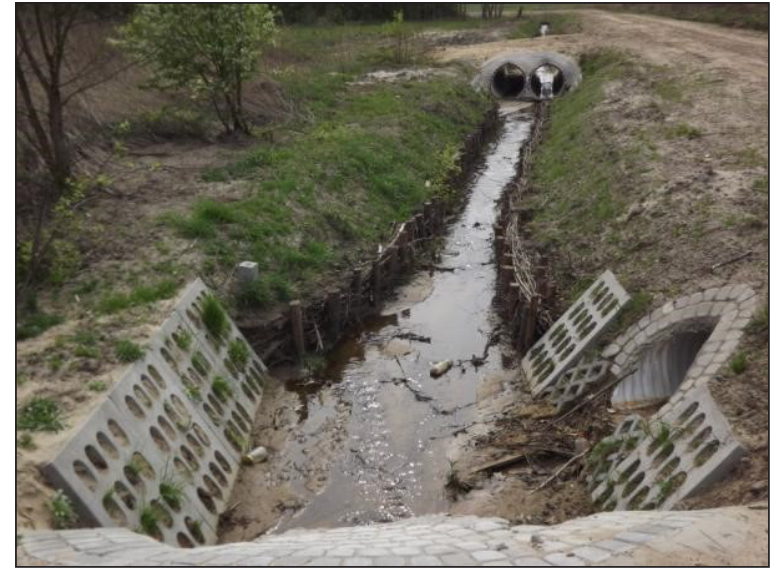

Photo 4. Example of a culvert draining water from roadside melioration ditches

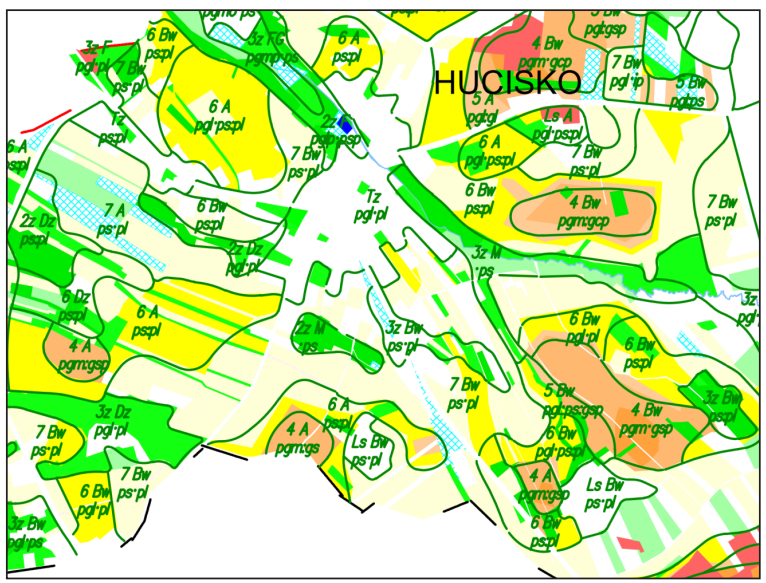

Fig. 2. Fragment of the soil-agricultural map of the studied consolidation area [on the basis of assumptions to the land consolidation project]

analysis of land fragmentation it can be concluded that the spatial structure of Hucisko is bad. There are very small farms here that are characterised by a large number of plots areas even smaller than 0.10 ha (over $50 \%$ of all plots). The structure of land fragmentation in the village under study is presented in Table 1.

\section{RESULTS AND DISCUSSION}

The environmental effects of land consolidation in the analysed area are as follows. In the area of Hucisko 3.10 ha of lands with low soil quality classes were set apart for afforestation, which was documented in the Local Spatial Development Plant for the village Hucisko, in the course of its development. In addition, for the area covered by the land consolidation it 
Table 1. Fragmentation of plots in the area of Hucisko

\begin{tabular}{|c|c|c|c|c|c|}
\hline \multirow{2}{*}{ Ranges of plot areas in ha: } & \multicolumn{2}{|c|}{ Number of plots } & \multicolumn{2}{c|}{ Areaa } & $\begin{array}{c}\text { Mean plot area in the } \\
\text { range of: }\end{array}$ \\
\cline { 2 - 5 } & number & $\%$ & Ha & $\%$ & [ha] \\
\hline $0-0,10$ & 1132 & 52,3 & 58,61 & 18,1 & 0,05 \\
\hline $0,11-0,20$ & 553 & 25,6 & 82,17 & 25,3 & 0,15 \\
\hline $0,21-0,30$ & 227 & 10,5 & 55,93 & 17,2 & 0,25 \\
\hline $0,31-0,50$ & 170 & 7,9 & 66,44 & 20,5 & 0,39 \\
\hline $0,51-1,00$ & 69 & 3,2 & 44,41 & 13,7 & 0,64 \\
\hline $1,00<$ & 12 & 0,6 & 16,67 & 5,1 & 1,39 \\
\hline Total: & $\mathbf{2 1 6 3}$ & $\mathbf{1 0 0 , 0 0}$ & $\mathbf{3 2 4 , 2 3}$ & $\mathbf{1 0 0 , 0 0}$ & $\mathbf{0 , 1 5}$ \\
\hline
\end{tabular}

Source: Own elaboration on the basis of data from the register of lands and buildings

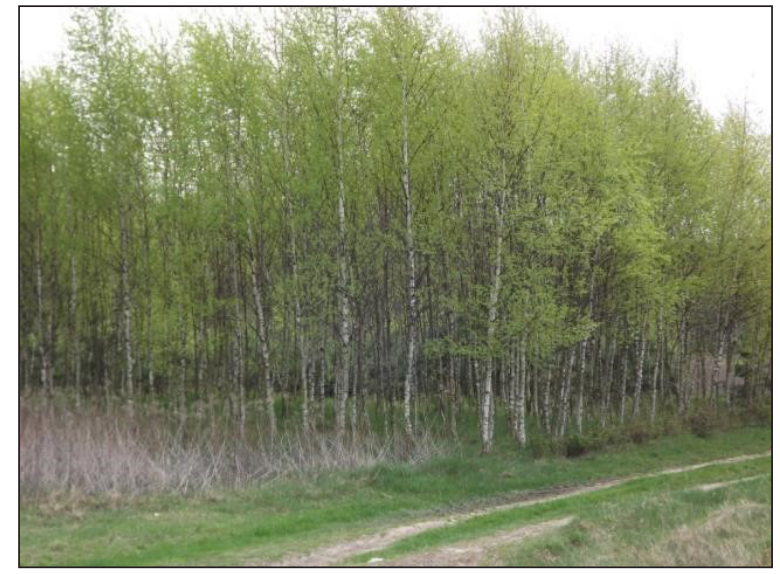

Photo 5. Example of peatbog overgrown with birch

was proposed to develop organic farming, farm tourism, maintenance and expansion, by future plantings, of mid-field tree coppices, maintenance of riverside and roadside trees, reduction of the use of chemical agents in fertilisation and pest control, no approvals for artificial lowering of the level of groundwater table, especially on the meadows, and a prohibition of wastewater disposal to the ground.

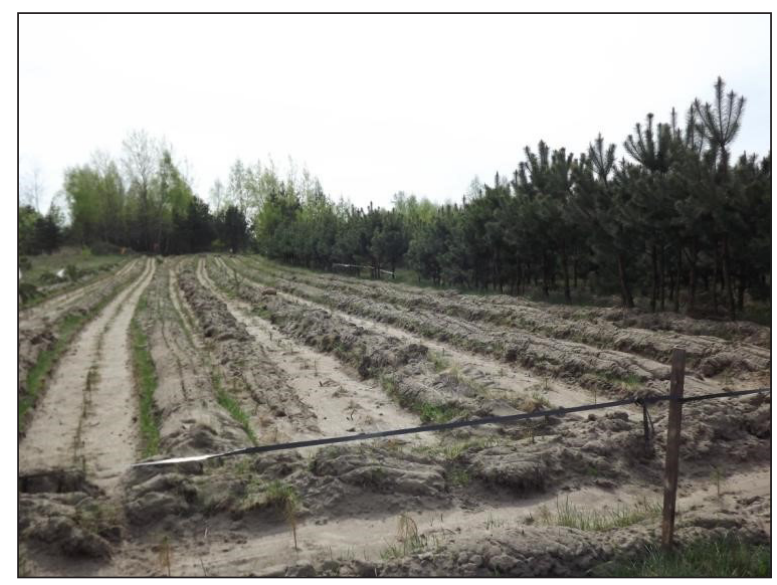

Photo 7. Example of area afforested in the framework of post-consolidation development

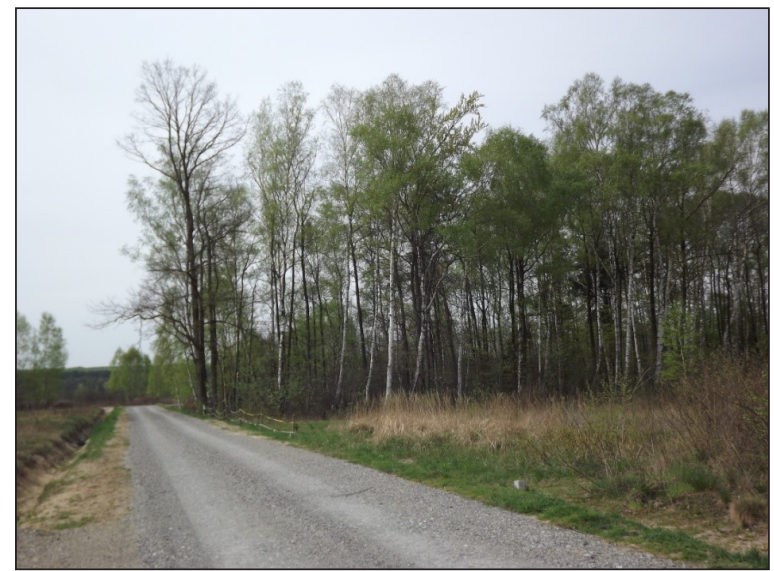

Photo 6. Example of peatbog overgrown with birch

As far as elements of water management are concerned, in the process of land consolidation existing culverts on detail melioration ditches were modernised, and new culverts were built in areas with difficult access to the public roads due to the existing network of melioration ditches. That modernisation caused an improvement of water relations, which had a positive effect on the water-air relations in the soil.

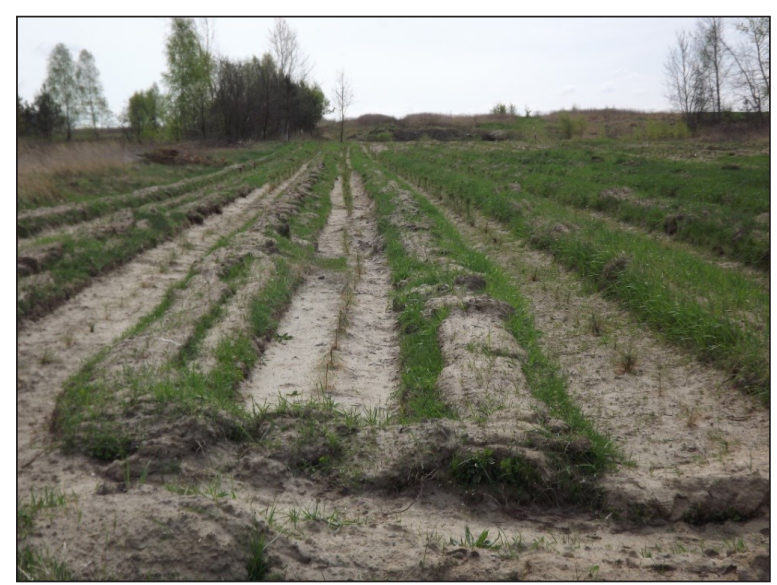

Photo 8. Example of area afforested in the framework of post-consolidation development 
Environmental protection measures applied within the area under analysis are as follows. According to information acquired from the Commune Office in Leżajsk, the village Hucisko is not situated in "Natura 2000" areas, but there is a protected area with the name of Brzóźniański Protected Landscape Area, with surface area of about 18.0 ha, situated in the south-eastern part of the village. That area was created in 1992 by a Decision of the Voivode of Rzeszów.

The historical buildings and monuments that are subject to protection and are listed in the Commune Register of Historical Buildings and Monuments in the area of the village Hucisko include the following:

- St. John of Dukla church built in the years 1977-1978,

- shrine of 1835 situated at the road to Maleniska,

- brick bell tower of 1880 ,

- forest guard lodge built in ca. 1900,

- wooden cottage No. 236 dated for the years 1885, 1927.

The implemented agricultural land management operation in the form of land consolidation in the village Hucisko did not cause any negative effects on the environment. It should be noted, however, that it caused a significant improvement of the natural conditions and improved the economic conditions in agriculture. The land consolidation operation included the following:

- renovation of existing network of melioration ditches,

- on a majority of the plots the original direction of the ditches was preserved, which prevented gravitational disturbance in water runoff,

- the existing roads were used to the maximum, thanks to which arable lands were not taken for access roads,

- the existing layout of plots and access roads in built-up areas was preserved. That eliminated the need to cut down trees near houses and to modify the existing technical infrastructure,

- afforested plots and grounds under afforestation plans with preservation of natural ecosystems were retained in the current state of use,

- reclamation of devastated and degraded soils that were destined for agricultural production.

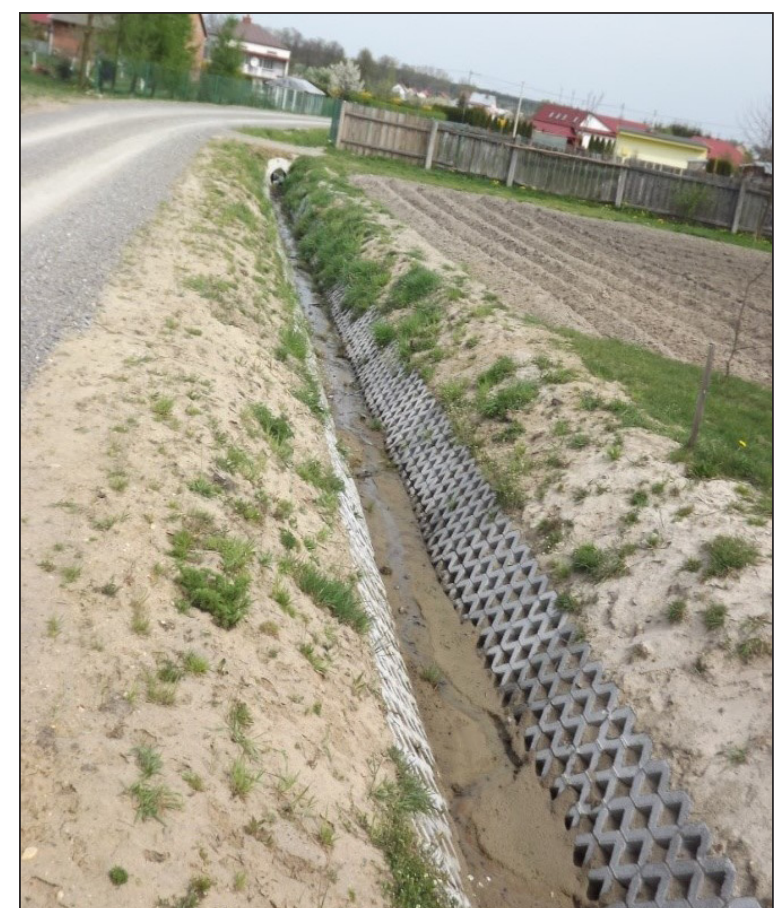

Photo 9. Example of renovated melioration ditch in the area of the consolidation

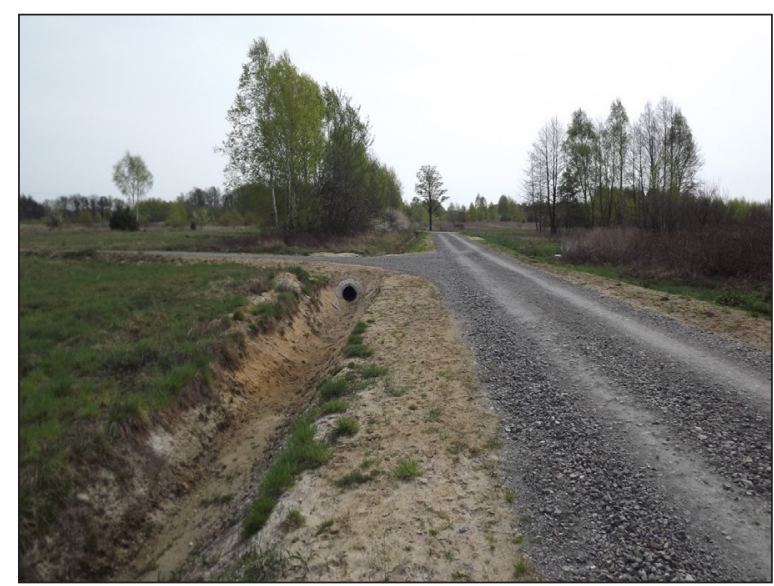

Photo 10. Example of new culvert built in the area of the consolidation

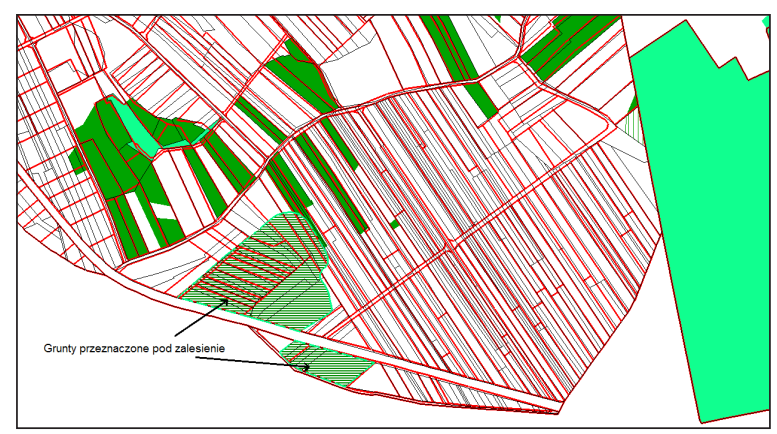

Fig. 3. Fragment of map of modified farmland [on the basis of assumptions to the land consolidation project] 


\section{CONCLUSIONS}

The primary objective of the land consolidation operation was to eliminate the problematic checkerboard of plots. The direct effects of the consolidation performed in the village Hucisko included the realization of the following assumptions:

1. Increase in the areas of lands for development based on the existing settlement system.

2. 3.10 ha of farmland were set apart for reclamation by afforestation.

3. Approximately 0.70 ha was used for an expansion of the cemetery.

4. The District Governor of the Leżajsk District applied to the State Treasury Agricultural Property Agency for assigning land for local public use purposes and for agricultural transport roads. The remaining parts of lands for those purposes was deducted from the property of the participants of the consolidation (maximum deduction was ca. $3-4 \%$ ). To serve the agricultural production space, $24.4 \mathrm{~km}$ of agricultural transport roads were designed, including roads within settlement areas. As far as possible, the roads were widened and adapted for the needs of modern agriculture. The width of agricultural transport roads falls within the range of 6-12m, taking into account roadside ditches. In total, 20 exits from district class roads were built.

5. Improvement of land layout in farms and reduction of the number of plots in a farm. The total number of plots was decreased from 2355 to 1568 . Also the shapes of the farmland plots were changed.

6. Access was designed to each of the resultant post-consolidation plots.

7. Reconstruction and renovation of melioration ditches, which will bring the meadows, currently waterlogged, to a state of usability. 7 culverts were built on the melioration ditches, in the belts of the newly designed roads. $80 \%$ of the melioration infrastructure required reconstruction and conservation.

8. The land reclamation operations included the following - elimination of old roads, elimination of bush-covered areas, bringing of fallow areas under use, filling of pits after sand and loam mining, the combined area of which was estimated at 40 ha.
The final effect of the land consolidation was the updated land registry statement on the basis of data from direct measurements in the field. Within the scope of the consolidation program, the boundaries of registered land lots were delineated, the layout and spatial arrangement of which remained unchanged in accordance with the wish of the participants of the consolidation. Whereas, the newly designed boundaries were stabilised in a permanent manner. As a result of the consolidation a numerical map was created, as well as the relevant geodetic-legal documentation that was required for proper representation of the new status in the land registry and in the property registration books.

\section{REFERENCES}

1. Dudzińska M. 2012. Szachownica gruntów rolnych jako czynnik kształtujący przestrzeń wiejską. Infrastruktura i Ekologia Terenów Wiejskich. Nr 2012/ 02 (3 (Sep 2012))

2. Gniadek J. 2013. Ocena przestrzennego ukształtowania działek różniczan na przykładzie Mciwojowa. W mat Infrastruktura i ekologia terenów wiejskich, Nr 3/II/2013 PAN, 133-143.

3. Król Ż. 2014. Charakterystyka szachownicy gruntów o układzie wstęgowym na przykładzie miejscowości Brzeziny gmina Puchaczów. Infrastruktura i Ekologia Terenów Wiejskich. Nr 2014/ II (2 (Jun 2014))

4. Król Ż., Leń P. 2016. Szachownica gruntów indywidualnych wyznacznikiem pilności wykonania prac scalenia i wymiany gruntów. Infrastruktura i Ekologia Terenów Wiejskich. Nr 2016/ II (1 (Apr 2016))

5. Leń P. (2009). Rozmiary gruntów różniczan i możliwości ich likwidacji (na przykładzie wsi w powiecie Brzozów, województwo Podkarpackie. Rozwój obszarów wiejskich - stan obecny i perspektywy, Puławy.

6. Leń P., Noga K. 2010. Analiza rozdrobnienia gruntów indywidualnych we wsiach powiatu $\mathrm{Br}$ zozów woj. Podkarpackie [In:] Infrastruktura i Ekologia Terenów Wiejskich, PAN w Krakowie.

7. Leń P. 2010. Analiza rozdrobnienia gruntów na przykładzie powiatu Brzozów [In:] Infrastruktura i Ekologia Terenów Wiejskich, Wydawca: PAN w Krakowie.

8. Leń P. 2012. Prawidłowości w rozmiarze występowania gruntów różniczan zamiejscowych na przykładzie wsi w powiecie Brzozów. [w]: Infrastruktura i Ekologia Terenów Wiejskich, PAN w Krakowie. 
9. Leń P., Dziadosz D., Kovalyshyn A. 2015a. Використання програми Quantum GIS під час аналізу просторової структури села Ольшаниця. Вісник. Серія: Економіка АПК, 2015.

10. Leń P., Bal A., Kovalyshyn A., Kryshenyk N. 2015b. Analiza struktury przestrzennej wsi Wólka Sokołowska w powiecie rzeszowskim, woj. Podkarpackie. Вісник, Волинського Інституту Економіки Та Менеджменту №13, 2015.

11. Leń P., Dziadosz D., Kovalyshyn A. 2015c. Rozmiary gruntów różniczan i możliwości ich likwidacji na przykładzie wsi Olszanica w powiecie leskim. Теорія і практика розвитку агропромислового комплексу та сільських територій Матеріали XVI міжнародного науково-практичного форуму 23-25 вересня 2015 p.

12. Leń P., Mika M. 2016a. Analysis of the flawed spatial structure of land in selected villages of the south-eastern Poland. Geomatics, Landmanagement and Landscape No. 2, 2016.

13. Leń P., Mika M. 2016b. The impact of socio-economic factors on the size of the external plot patchwork on the example of Brzustowiec village, in the Łódzkie Voivodship. Geomatics And Environmental Engineering Vol. 10/2 2016.

14. Leń P., Mika M. 2016c. Ranking przeznaczenia obszarów do prac scaleniowych, ze względu na rozmiary szachownicy gruntów, na przykładzie gminy Sławno. Infrastruktura i Ekologia Terenów Wiejskich. Nr 2016/ II (1 (Apr 2016))

15. Leń P., Mika M., Wójcik-Leń J. 2016. Estimation of the size of the external land patchwork based on test areas in podkarpackie voivodship in Poland. Geomatics, Landmanagement and Landscape No. $1,2016$.

16. Noga K. 2001. Metodyka programowania i real- izacji prac scalenia i wymiany gruntów w ujęciu kompleksowym. Szkoła wiedzy o terenie. Kraków.

17. Noga K. Schilbach J. 1993. Metodyka przekształcania wadliwej struktury przestrzennej rolnictwa w terenach górskich. Zeszyty Naukowe Akademii Rolniczo-Technicznej w Olsztynie nr 22, 153-161

18. Podkarpackie Biuro Geodezji i Terenów Rolnych w Rzeszowie: „Karta Informacyjna Przedsięwzięcia: Scalenie Gruntów wsi Hucisko, gm. Leżajsk, pow. leżajski, woj. Podkarpackie”. Rzeszów 2011.

19. Podkarpackie Biuro Geodezji i Terenów Rolnych w Rzeszowie: „Założenia do projektu scalenia gruntów Hucisko, gm. Leżajsk, pow. leżajski, woj. Podkarpackie". Rzeszów 2011.

20. Sobolewska-Mikulska K. Gospodarka terenami na obszarach wiejskich w Polsce jako element polityki rolnej Unii Europejskiej, Materiały międzynarodowej konferencji „XI Dni Geodezji”, Polańczyk 2005.

21. Sobolewska-Mikulska K. Pułecka A. 2007. Scalenia i wymiany gruntów w rozwoju obszarów wiejskich. Oficyna Wydawnicza Politechniki Warszawskiej, Warszawa

22. Trystuła A. Scalanie gruntów jako jeden z elementów urządzenia przestrzeni wiejskiej w Polsce i na Litwie. Instytut Melioracji i Użytków Zielonych. Falenty 2008.

23. Ustawa z dnia 21 sierpnia 1997 r. o gospodarce nieruchomościami art. 1-4, art. 65 (Dz. U. z 2015 r. poz. 1774, z późn. zmianami).

24. Wójcik G., Leń P. 2015. Spatial development of agricultural land division throughout the ages in villages of the Opoczno County. Geomatics And Environmental Engineering Vol. 9/3 2015.

Pracę dofinansowano ze środków Wojewódzkiego Funduszu Ochrony Środowiska i Gospodarki Wodnej w Lublinie. 